\title{
Energy from Waste: Reuse of Compost Heat as a Source of Renewable Energy
}

\author{
G. Irvine, E. R. Lamont, and B. Antizar-Ladislao \\ School of Engineering, Institute for Infrastructure and Environment, University of Edinburgh, William Rankine Building, \\ The King's Buildings, Edinburgh EH9 3JL, UK \\ Correspondence should be addressed to B. Antizar-Ladislao, b.antizar-ladislao@ed.ac.uk
}

Received 10 December 2009; Accepted 14 April 2010

Academic Editor: Michael K. Danquah

Copyright ( 2010 G. Irvine et al. This is an open access article distributed under the Creative Commons Attribution License, which permits unrestricted use, distribution, and reproduction in any medium, provided the original work is properly cited.

An in-vessel tunnel composting facility in Scotland was used to investigate the potential for collection and reuse of compost heat as a source of renewable energy. The amount of energy offered by the compost was calculated and seasonal variations analysed. A heat exchanger was designed in order to collect and transfer the heat. This allowed heated water of $47.3^{\circ} \mathrm{C}$ to be obtained. The temperature could be further increased to above $60^{\circ} \mathrm{C}$ by passing it through multiple tunnels in series. Estimated costs for installing and running the system were calculated. In order to analyse these costs alternative solar thermal and ground source heat pump systems were also designed. The levels of supply and economic performance were then compared. A capital cost of $£ 11,662$ and

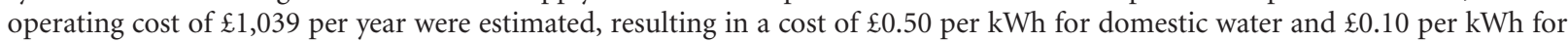
spatial heat. Using the heat of the compost was found to provide the most reliable level of supply at a similar price to its rivals.

\section{Introduction}

Composting is an aerobic process where organic materials are biologically decomposed, producing mainly compost, carbon dioxide, water, and heat. Conventional composting processes typically comprise four major microbiological stages in relation to temperature: mesophilic, thermophilic, cooling, and maturation, during which the structure of the microbial community also changes, and the final product is compost [1]. In recent years, the development and widespread use of more expensive in-vessel systems for the processing of biowastes has resulted from legislative pressures on the safety of the composting process and the subsequent use of the compost product [2]. Such systems allow for much more precise control of the composting process particularly in terms of moisture and temperature control [3]. Thus, current composting approaches and technologies tend to emphasize the use of high temperatures $\left(>70^{\circ} \mathrm{C}\right)$ in order to meet regulatory requirements for pathogen control [2].

Compost has been widely used as soil conditioners and soil fertilizers. This practice is recommended, as soil fertility needs more than ever to be sustained. Food demand is increasing rapidly in non-OECD (Organisation for Economic Co-operation and Development) countries, and it is in those countries particularly where organic waste needs to be diverted from landfill sites to composting practices, so compost can enhance soil fertility [4]. In OECD countries, where composting of organic waste is already established, its use as a landfill cover to abate greenhouse gas emissions has shown to be promising [5]. The addition of compost can minimize land degradation and soil erosion. Additionally, composting can contribute to achieve sufficient hygienisation of organic wastes and control soilborn and airborn pathogens by promotion of beneficial micro-organisms and suppression of harmful micro-organisms [6].

As energy demand is increasing rapidly, bionergy is seen as one of the primary possibilities for preventing global warming [7]. At present, the immediate factor impeding the emergence of an industry converting biowastes into bioenergy on a large scale is the high cost of processing, rather than the cost or availability of biomass feedstock [8]. Thus, the challenge is to extend the amount of bioenergy that can be produced sustainably by using biowastes, such as municipal, industrial, and construction waste as biomass feedstocks [9]. Thus, it is suggested that the heat generated during composting processes can be reused as a renewable source of energy. 
A limited number of previous studies has investigated the potential energy content of compost. A recent study reports that during high-temperature phases $\left(\sim 60^{\circ} \mathrm{C}\right)$ of municipal waste composting, on average $1136 \mathrm{~kJ} \mathrm{~kg}^{-1}$ of heat was released [10]. Similar values $\left(961 \mathrm{~kJ} \mathrm{~kg}^{-1}\right)$ have been reported earlier with an average compost moisture content of $52.7 \%$ [11]. Heat produced during the composting of wheat straw and poultry droppings was approximately $17.06 \mathrm{MJ} \mathrm{kg}^{-1}[12]$ and $12.8 \mathrm{MJ} \mathrm{kg}^{-1}$ [13], respectively. Additionally, it has been reported that the compost from municipal waste is characterised by fairly low values of thermal conductivity coefficient $\left(0.31 \mathrm{Wm}^{-1} \mathrm{~K}^{-1}\right.$ for a compost density of $\left.600 \mathrm{~kg} \mathrm{~m}^{-3}, 60^{\circ} \mathrm{C}\right)$, and that an increase in temperature or density both lead to an increase in the thermal conductivity coefficient [10]. Thus, as the compost ages, and it suffers a reduction in density and temperature, the thermal conduction coefficient will decrease. Klejment and Rosiński (2008) concluded that the low value of heat conductivity coefficients does not allow compost to cool too fast and enables the application of a battery of heat exchangers. A limited number of studies on compost heat reuse has also been reported. Lekic [14] investigated the increase in water temperature between the inlet and the outlet of polyethylene pipes embedded in composting windrows and reported that $73 \%$ of the theoretical value of heat energy was transferred to the water. One main limitation of this study was the placement of the pipes within the compost mass. A solution proposed by Seki and Komori [15] involved using a packed column heating tower that transfers the heat from the warm exhaust air of the compost to a volume of water.

From the above, it is fully justified to investigate the potential reuse of compost heat as a source of renewable energy. Our primary objectives were (a) to identify the potential energy available through full-scale in-vessel composting units; (b) to identify potential technological solutions to harnessing/collecting the energy; (c) to identify the optimum alternative use for the energy collected; and (d) to critically evaluate the potential of reusing that heat from compost by comparing the performance with alternative renewable energies.

\section{Materials and Methods}

2.1. Site Description. This case study was focused upon the Deerdykes Composting Facility located in Scotland, UK. The facility was originally constructed on the site of a decommissioned sewage treatment works, where much of the existing infrastructure was able to be reused for the composting facility. Work was completed in 2006, and the site currently accepts green waste, industrial sludge, and liquid waste [16]. The main components of the site are the site office, the invessel composting tunnels, the windrow composting area, and the raw material mixing area (Figure 1).

2.2. In-Vessel Units' Description and Operation. There are 8 in-vessel composting tunnels that were constructed in the former presettlement tanks [16]. The dimensions of the tunnels varied with tunnels $1-4$ being $5 \mathrm{~m}$ wide and $25 \mathrm{~m}$
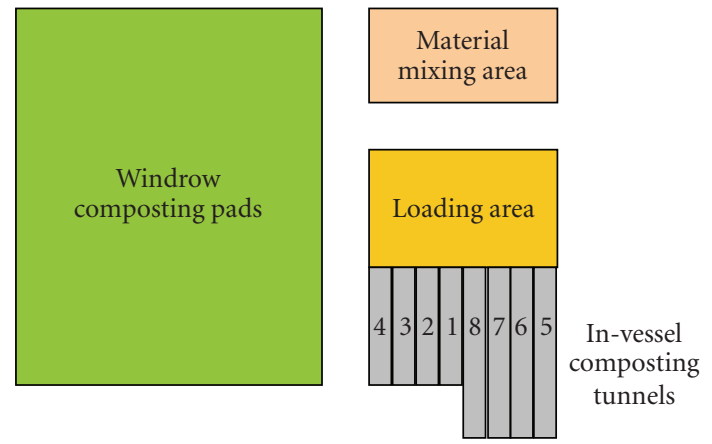

Site office

FIGURE 1: Deerdykes site layout.

long, tunnels 5 and 6 being $5.3 \mathrm{~m}$ wide and $35 \mathrm{~m}$ long, and tunnels 7 and 8 being $5 \mathrm{~m}$ wide and $35 \mathrm{~m}$ long. The tunnels were all approximately $5 \mathrm{~m}$ in height, however, compost was only loaded to a height of $3 \mathrm{~m}$ (Figure 2). Compost was loaded for an average period of 12-17 days, allowing a sanitary and stable condition of compost to be achieved. Air was supplied through small aeration holes in the floor of the tunnel thus ensuring aerobic conditions were maintained throughout the compost mass. The air drawn off from the top was primarily recirculated through the compost with a small portion expelled as exhaust air. Additionally, fresh air was mixed with the recirculated air to ensure oxygen concentrations were maintained at acceptable levels.

The exhaust air was put through two stages of treatment. Firstly, the wet scrubber removed ammonia, hydrogen sulphide, and volatile fatty acids whilst cooling the warm air. Secondly, the biofilter removed any remaining concentrations of the pollutants and provided odour control, allowing the air to be released to the atmosphere. Potential production of methane, a potent green house gas, in anaerobic "pockets" within the composting pile, would have either metabolically oxidized to carbon dioxide while the percolated through the composting pile, or during its passage through the biofilter. Thus emissions of green house gases were not expected.

The in-vessel composting process was completely computer controlled by a software package specifically designed for the process. The air flow rates for all air blowers were varied automatically depending on the current temperature, oxygen, and pressure levels inside the tunnel. A userdefined minimum oxygen content was maintained whilst aiming to maximise the temperature, and thus degradation rate, of the compost [16]. Once the two-week period was complete the degraded compost material was transferred to the neighbouring windrow pads where it was allowed to decompose for a further 6 weeks.

2.3. Temperature Profiles. Temperature values for each batch of compost and in-vessel unit were gathered during JanuaryDecember 2008 for analysis. The data stated the temperatures measured by each of the 8 temperature probes that were 


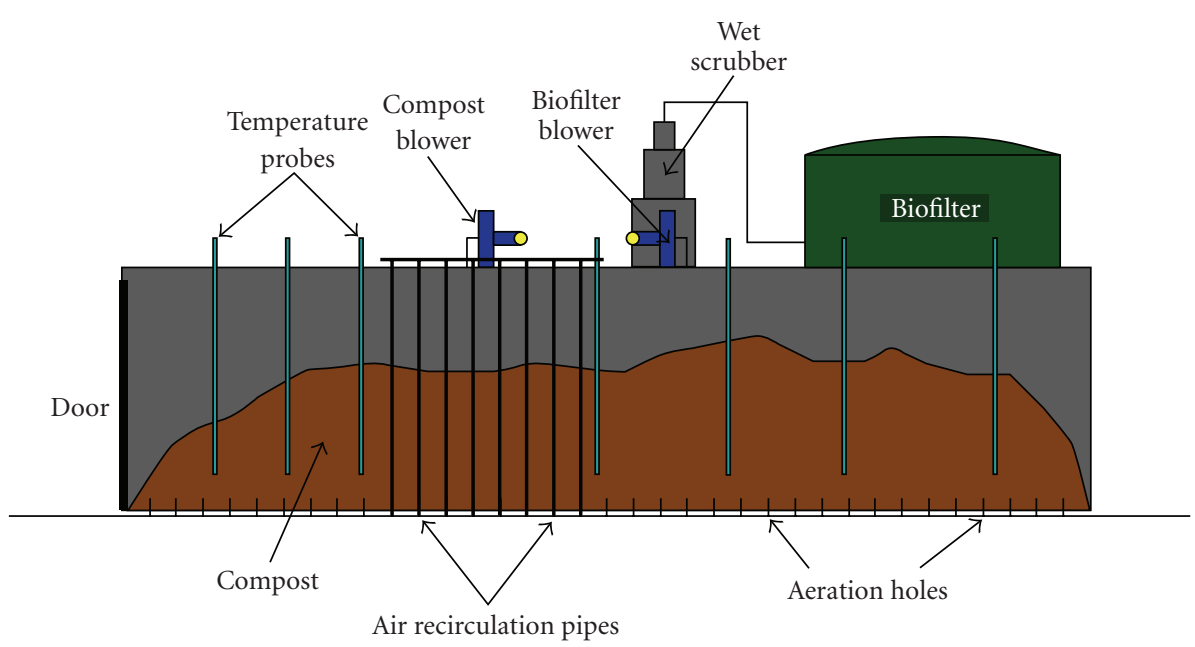

FIGURE 2: In-vessel unit cross-section.

placed into the mass of compost inside the tunnel. Results were recorded with a regular time step of 15 minutes, with the occasional exception, throughout the whole of the degradation process. The 8 temperature values were averaged for each batch in order to derive an overall time-temperature relationship. Any readings that were clearly incorrect were disregarded.

Individual time-temperature relationships were then accumulated by season allowing overall trends to be analysed. Subsequently an average time-temperature relationship for each of the four seasons could be created.

2.4. On-Site Hot Water Demand. The average value for daily hot water consumption for the Deerdykes composting facility's site office was calculated at $180 \mathrm{~L} \mathrm{~d}^{-1}$. A medium heating requirement of $12 \mathrm{~kW}$ for the site office was estimated, which ranged from poorly isolated buildings with a very high heating load of $22 \mathrm{~kW}$ [17] to an Eco-House with a required heating load of $8 \mathrm{~kW}[18]$. It was assumed that the heating would be used on average 980 hours per year.

2.5. Energy Values. Energy values were then calculated for each of the four seasons. The method used was of that described by Haug [1] using the standard heat flow into a substance at constant pressure equation. This equation was also utilised in energy-balanced analyses carried out by other researchers in composting systems [19].

The following equation was used:

$$
q_{p}=m \times c_{p} \times \Delta T,
$$

where $q_{p}$ is heat energy leaving the system $\left(\mathrm{kJ} \mathrm{kg}^{-1}\right), m$ is mass of product $(\mathrm{kg}), c_{p}$ is specific heat at a constant pressure $\left(\mathrm{kJ} \mathrm{kg}^{-1} \mathrm{~K}^{-1}\right)$, and $\Delta T$ is change in temperature $(\mathrm{K})$. This equation assumes a process at constant pressure with a constant specific heat capacity. This assumption is valid for the relatively small changes in pressure and temperature associated with composting [1]. Heat energy values were calculated for each time step using estimated
TABlE 1: Estimated material composition for composting at Deerdykes.

\begin{tabular}{lccc}
\hline Material & $\%$ present & $\begin{array}{c}\mathrm{c}_{\mathrm{p}} \\
\left(\mathrm{kJ} \mathrm{kg}^{-1} \mathrm{~K}^{-1}\right)\end{array}$ & $\begin{array}{c}\text { Overall } \mathrm{c}_{\mathrm{p}} \\
\left(\mathrm{kJ} \mathrm{kg}^{-1} \mathrm{~K}^{-1}\right)\end{array}$ \\
\hline Air & $10 \%$ & 1.012 & \\
Water & $60 \%$ & 4.184 & 2.844 \\
Soil & $28 \%$ & 0.80 & \\
Lignocellulosic material & $2 \%$ & 0.42 & \\
\hline
\end{tabular}

compost material concentrations and standard specific heat capacity values (Table 1 ). The energy values were then accumulated by day to give the energy stored in $\mathrm{kJ} \mathrm{kg}^{-1}$ day ${ }^{-1}$. Cumulative energy over the 15 -day composting period was also calculated.

2.6. Heat Exchange and Energy Collection. A heat exchanger was designed for the collection of energy generated during composting. The heat exchanger selected for the purpose of this study was a pipeline made of stainless steel that run suspended from the top of the in-vessel tunnels in the airspace above the composting piles. At the initial calculation stage the length and diameter of pipe required was unknown so the initial pipe layout shown in Figure 3 was investigated. The design of the heat exchanging element of the proposed design was carried out using the principles and methods discussed by Shah and Sekulic [20].

Nomenclature used in the following section is summarized in Table 2. The aim of the design process was to determine the outlet temperature for both the hot and cold fluid for a suggested heat exchanger surface area

2.6.1. Hot Fluid. In this case study, the hot fluid was the warm, moist air that is released by the composting process and circulated throughout the tunnel. The temperature of this air was dictated by the temperature of the compost itself; the majority of the air was recirculated. The temperature of the air approached that of the compost after the process 
TABLE 2: Nomenclature.

\begin{tabular}{|c|c|c|}
\hline Parameter $^{\mathrm{a}}$ & Description & Unit \\
\hline$T_{, i}$ & Temperature of the fluid entering the system & $\mathrm{K}$ \\
\hline$T_{, o}$ & Temperature of the fluid leaving the system & K \\
\hline$\dot{m}$ & Mass flow rate of the fluid & $\mathrm{kg} \mathrm{s}^{-1}$ \\
\hline$c_{p}$ & Specific heat capacity of the fluid at constant pressure & $\mathrm{kJ} \mathrm{kg}^{-1} \mathrm{~K}^{-1}$ \\
\hline$d_{i}$ & Inner diameter of the heat exchanger pipe & $\mathrm{m}$ \\
\hline$d_{o}$ & Outer diameter of the heat exchanger pipe & $\mathrm{m}$ \\
\hline$k_{w}$ & Thermal conductivity value of the pipe wall material & $\mathrm{W} \mathrm{m}^{-1} \mathrm{~K}^{-1}$ \\
\hline$h_{\mathrm{AIR}}$ & Heat transfer coefficient of air & $\mathrm{W} \mathrm{m}^{-2} \mathrm{~K}^{-1}$ \\
\hline$h_{\text {WATER }}$ & Heat transfer coefficient of water & 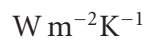 \\
\hline$A$ & Surface area of the heat exchanger wall & $\mathrm{m}^{2}$ \\
\hline
\end{tabular}

${ }^{a}$ The subscript $h$ refers to the initially hotter fluid, and the subscript $c$ refers to the initially colder fluid.

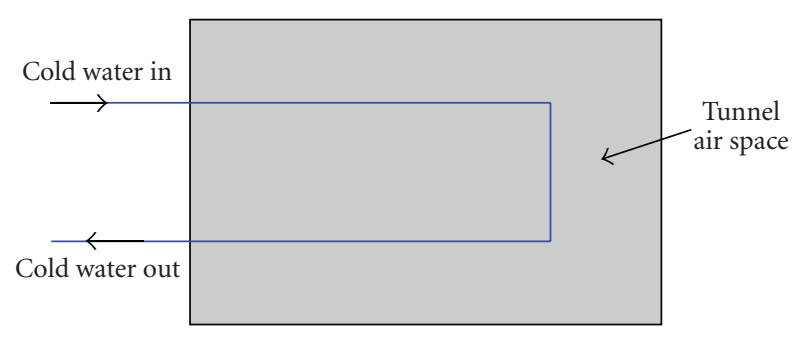

FIgURE 3: Initial design pipe layout.

has been running for a certain period. The only other effect on the temperature of the air was through heat conductive losses through the concrete walls and roof of the tunnel. The mass flow rate of the air through the tunnel was driven by a centrifugal blower the maximum capacity of which was $8000 \mathrm{~m}^{3} \mathrm{hr}^{-1}$. These blowers were controlled in real time by computer to regulate oxygen and moisture levels.

2.6.2. Cold Fluid. It was proposed to use water as the cold fluid that runs through the pipe work of the heat exchanger. This was due to its low cost, ease of availability, and its thermal properties which were optimal for absorbing and storing thermal energy [21]. The mass flow rate of the water was fully controllable by the design team. A pump, pressure, or gravity fed system was designed according to requirements.

2.6.3. Individual Heat Transfer Coefficient. The individual heat transfer coefficient was calculated using

$$
h=\frac{\Delta Q}{A \times \Delta T \times \Delta t},
$$

where $\Delta Q$ is the heat input or heat lost $(\mathrm{J}), h$ is the heat transfer coefficient, $\left(\mathrm{W} \mathrm{m}^{-2} \mathrm{~K}^{-1}\right), A$ is the heat transfer surface area $\left(\mathrm{m}^{2}\right), \Delta T$ is the temperature difference between the solid surface and surrounding fluid $(\mathrm{K})$, and $\Delta t$ is the time period (s).

2.6.4. Overall Heat Transfer Coefficient. The overall heat transfer of the pipe was calculated by summing the individual heat transfer coefficients of the acting fluids using [20]

$$
\frac{1}{U}=\frac{1}{h_{o}}+\frac{1}{h_{o, f}}+\frac{d_{o} \ln \left(d_{o} / d_{i}\right)}{2 k_{w}}+\frac{d_{o}}{h_{i, f} d_{i}}+\frac{d_{o}}{h_{i} d_{i}},
$$

where the subscripts $o$ and $i$ refer to the outside and inside of the pipe wall, respectively, $U$ is the overall heat transfer coefficient $\left(\mathrm{W} \mathrm{m}^{-2} \mathrm{~K}^{-1}\right)$, and $h_{f}$ is the thermal fouling resistance capacity $\left(\mathrm{W} \mathrm{m}^{-2} \mathrm{~K}^{-1}\right)$.

2.6.5. Design Equations. The heat capacity rates for each fluid were calculated using [20]

$$
C=\dot{m} c_{p} .
$$

Subsequently the heat capacity ratio, $C^{*}$, could be calculated using (5). The heat capacity ratio is simply the smaller-tolarger ratio of the heat capacity rates of the two fluids

$$
C^{*}=\frac{C_{\min }}{C_{\max }} .
$$

The next step was to calculate the ratio of the overall thermal conductance to the smaller of the two heat capacities, which is defined as the number of transferred units (NTUs). This was found with the following equation:

$$
\mathrm{NTU}=\frac{\mathrm{UA}}{C_{\min }} .
$$

Once these values were obtained the exchanger effectiveness, $\varepsilon$, was calculated. The equation for exchanger effectiveness depends on the type and flow direction associated with the particular exchanger being designed. In this case study (7) was used as it is appropriate for the counter-flow conditions that existed in the tunnel [20]

$$
\varepsilon=\frac{1-\exp \left[-\mathrm{NTU}\left(1-C^{*}\right)\right]}{1-C^{*} \exp \left[-\mathrm{NTU}\left(1-C^{*}\right)\right]} .
$$

Once the exchanger effectiveness was calculated the fluid outlet temperature was found using

$$
\varepsilon=\frac{C_{h}\left(T_{h, i}-T_{h, o}\right)}{C_{\min }\left(T_{h, i}-T_{c, i}\right)}=\frac{C_{c}\left(T_{c, o}-T_{c, i}\right)}{C_{\min }\left(T_{h, i}-T_{c, i}\right)} .
$$


TABLe 3: Monthly solar irradiation $\left(\mathrm{kW} \mathrm{h} \mathrm{m}^{-2}\right)$ for Glasgow, UK (DGS 2005).

\begin{tabular}{|c|c|c|c|c|c|c|c|c|c|c|c|c|}
\hline Month & Jan & Feb & Mar & Apr & May & Jun & Jul & Aug & Sep & Oct & Nov & Dec \\
\hline Irradiance & 0.45 & 1.04 & 1.94 & 3.40 & 4.48 & 4.70 & 4.35 & 3.48 & 2.33 & 1.26 & 0.60 & 0.32 \\
\hline
\end{tabular}

\subsection{Comparison of Waste to Energy with Other Renewable} Energies. Compost heat as a source of renewable heat was compared to solar thermal systems and to ground-source heat. The solar thermal system was designed using the good-practice guidelines discussed by DGS [17], which was originally written with a single-family house in mind which proved transferable to the purpose in this case study. Design methods were discussed separately for both domestic hot water supply and spatial heating.

Supplying domestic hot water is the most common use for solar thermal systems. The following sizing calculations allowed a full design to be proposed. Using the calculated value of hot water demand for the site office, $V_{\mathrm{HW}}$, the heat requirement was determined using

$$
Q_{\mathrm{HW}}=V_{\mathrm{HW}} \times c_{p} \times \Delta T,
$$

where $Q_{\mathrm{HW}}$ is the daily heat requirement $\left(\mathrm{kWh}\right.$ day $\left.^{-1}\right), V_{\mathrm{HW}}$ is the daily hot water consumption $\left(\mathrm{L} \mathrm{day}^{-1}\right), c_{p}$ is the specific heat capacity of water ( $\mathrm{Wh} \mathrm{kg}^{-1} \mathrm{~K}^{-1}$ ), and $\Delta T$ is the temperature difference between the hot and cold water $(\mathrm{K})$.

In order to calculate the area of the solar collector required the desired solar fraction, $\mathrm{SF}$, and the overall average system efficiency, $\eta_{\text {SYS }}$, of the solar collector were found. The SF is the ratio of solar heat yield to total energy required by the building and is shown by (10). It showed what percentage of the yearly heat energy demand is to be supplied by solar rather than conventional means

$$
\mathrm{SF}=\frac{Q_{\mathrm{S}}}{Q_{\mathrm{S}}+Q_{\mathrm{AUX}}} \times 100
$$

where SF is the desired solar fraction, $Q_{S}$ is the solar heating requirement $(\mathrm{kWh})$, and $\mathrm{Q}_{\mathrm{AUX}}$ is the auxiliary heating requirement $(\mathrm{kWh})$.

Achieving as high a solar fraction as possible would appear desirable, however due to the variable nature of solar energy throughout the year in temperate zones it is advisable to aim for a solar fraction of around 60\% [17]. Aiming for a solar fraction of $60 \%$ prevented the supply of hot water becoming overly stressed during the winter months, due to the provision of a backup boiler supply.

If aiming to counter this by using a large area of solar collectors to better cope with winter months, it will result in an oversupply of hot water during the summer months, thus a much less efficient design. For these reasons as the solar fraction increases the system efficiency decreases. When coupled with the high set-up costs associated with a scheme of that kind it proved to be an option that limits the economic attractiveness of solar thermal systems [17].

The average system efficiency is the ratio of solar heat yield to global solar irradiance experienced by the absorber surface and is linked to the solar fraction. Average system efficiencies $\eta_{S Y S}$ take into account losses at the collector, solar circuit, and storage. Guidelines state that initial calculations should assume a $\eta_{\text {SYs }}$ of 0.35 for a flat-plate collector and 0.45 for an evacuated-tube collector [17]. This data was then used to calculate the required area of solar collector using (11). The yearly solar irradiance value, $E_{G}$, was calculated for Glasgow (Table 3):

$$
A=\frac{365 \text { days } \times Q_{\mathrm{HW}} \times \mathrm{SF}}{E_{G} \times \eta_{\mathrm{SYS}}},
$$

where $A$ is absorber surface area $\left(\mathrm{m}^{2}\right), Q_{H W}$ is the daily heat requirement $\left(\mathrm{kWh}_{\mathrm{day}}{ }^{-1}\right), \mathrm{SF}$ is the desired solar fraction, $E_{G}$ is the yearly potential solar irradiance $\left(\mathrm{kWh} \mathrm{m}^{-2}\right.$ year $\left.^{-1}\right)$, and $\eta_{\text {SYS }}$ is the average system efficiency.

In order to calculate the optimal diameter for the piping of the solar circuit it is vital to regulate both the speed of flow and the volumetric flow. In order to minimise noise nuisance and prevent abrasion a flow speed, $v$, of $0.7 \mathrm{~m} \mathrm{~s}^{-1}$ is to be aimed for [17]. The level of volumetric flow is key in keeping the collector cooling at an efficient rate, preventing overheating and therefore wasting energy. It has been shown that a volumetric flow of about $40 \mathrm{~L} \mathrm{hr}^{-1}$ per $\mathrm{m}^{2}$ of collector area is ideal [17]. The volumetric flow was calculated using

$$
\dot{m}=\frac{\dot{Q}}{c_{p} \times \Delta T},
$$

where $\dot{m}$ is the volumetric flow $\left(\mathrm{L} \mathrm{m}^{-2} \mathrm{hr}^{-1}\right), \dot{Q}$ is the usable thermal output converted by the collector $\left(\mathrm{W} \mathrm{m}^{-2} \mathrm{hr}^{-1}\right), c_{p}$ is the specific heat capacity of the solar fluid $\left(\mathrm{kJ} \mathrm{kg}^{-1} \mathrm{~K}^{-1}\right)$, and $\Delta T$ is the temperature difference between the feed and the return flows $(\mathrm{K})$.

Subsequently the optimum pipe diameter, $D$, could be calculated using

$$
D=\sqrt{\frac{4(\dot{m} / v)}{\pi}} .
$$

This calculation allowed an appropriate size of commercially available pipe to be proposed. The recommended method for calculating the collector area required to fulfill spatial heating demand is currently far less developed than for domestic hot water supply [17]. This is due to the highly variable nature of the thermal insulation of buildings, individual preferences for the comfortable temperature of a room, and whether the building uses conventional or underfloor heating systems. The calculation method used was of that described by DGS (2005) which is based solely on the living area required to be heated. The relationships presented in Table 4 are valid for a climate with a low solar fraction of $35 \%$ such as the UK and were used to calculate the collector surface area and storage volume that would be required [17]. 
TABLE 4: Design guidelines for solar thermal spatial heating system.

\begin{tabular}{ll}
\hline Parameter & Recommended value \\
\hline Evacuated tube collector & $\begin{array}{l}0.5-0.8 \mathrm{~m}^{2} \text { of collector area per } 10 \mathrm{~m}^{2} \\
\text { heated living area }\end{array}$ \\
Storage volume & $>50 \mathrm{~L}$ per $\mathrm{m}^{2}$ of collector surface area \\
\hline
\end{tabular}

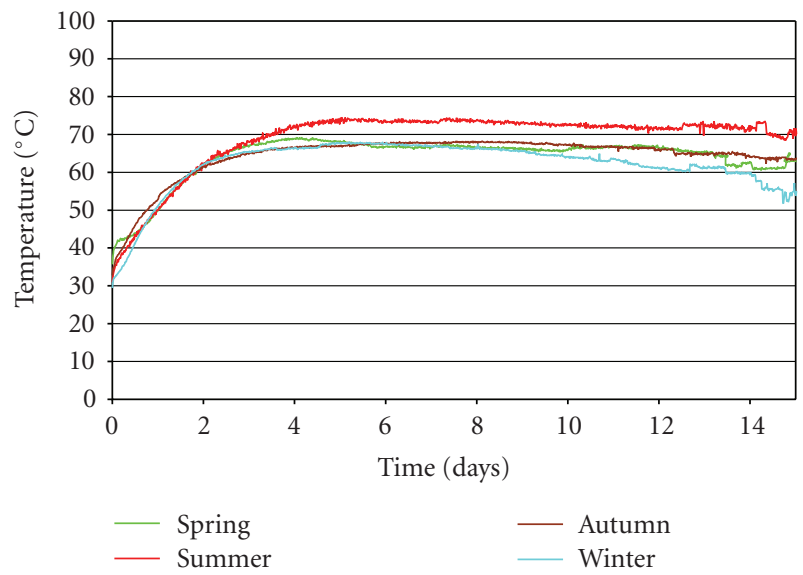

FIGURE 4: Average temperature temporal profiles: seasonal comparison.

Regarding a ground source heat pump design, generic design guidelines for specifying ground source heat pumps are currently at an underdeveloped stage.

\section{Results and Discussion}

3.1. Temperature and Energy Values. Figure 4 shows the seasonal average temperature temporal profiles between January and December 2008. The compost reached temperatures above $60^{\circ} \mathrm{C}$ after two days, and the highest values $\left(\sim 70^{\circ} \mathrm{C}\right)$ were recorded during the summer. This time is similar (2-4 days) to that observed when composting with one direction of airflow [22], but higher than that observed (0.63 days) using high recirculation of processed air [19]. Average temperatures at the end of day 12 of composting were above $65^{\circ} \mathrm{C}$ during spring, summer, and autumn, and about $60^{\circ} \mathrm{C}$ during the winter, which was close to the values reported by Harper et al. [23] for 1.5-2 $\mathrm{m}$ of compost depth and 7 days of composting and by Ekinci et al. [19] for pilot scale $208 \mathrm{~L}$ reactors, $0.285 \mathrm{~m}$ in radius, and $0.816 \mathrm{~m}$ in height.

Energy values were calculated using these average temperature profiles, and they are presented in Figure 5, where Figure 5(a) presents daily energy values and Figure 5(b) presents cumulative energy values. In this study, maximum heat generation rate per initial mass of compost dry matter was $\sim 6000 \mathrm{~kJ} \mathrm{~kg}^{-1} \mathrm{day}^{-1}$. This value was higher than that reported by Harper et al. [23] for straw and poultry manure composting (2791 kJ kg-1 day ${ }^{-1}$ ), and by Ekinci et al. [19] for paper mill sludge with broiler litter $\left(2435 \mathrm{~kJ} \mathrm{~kg}^{-1} \mathrm{day}^{-1}\right)$. Negative values in Figure 5(a) can be explained by the overall energy losses being greater than the energy emitted on those particular days, as the in-vessel systems were not hermetically closed.

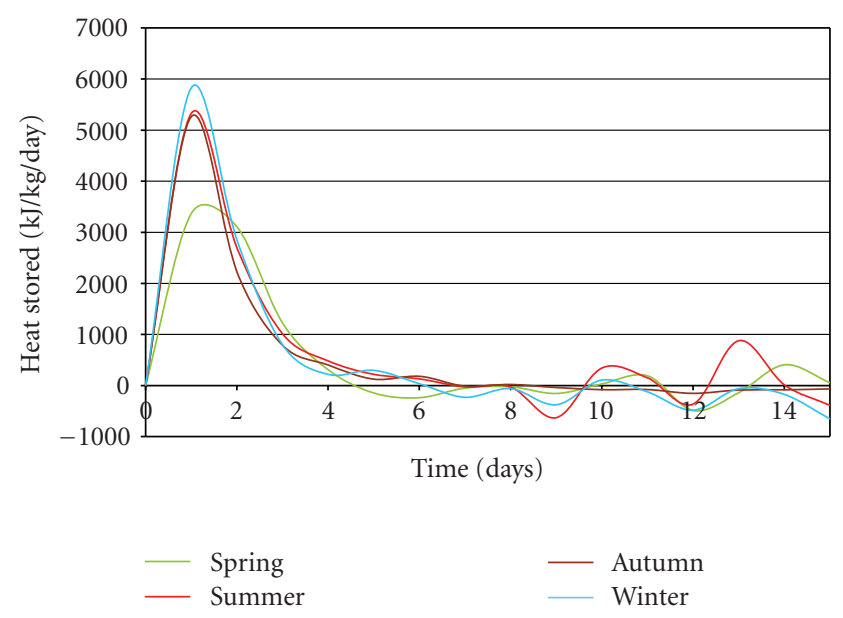

(a)

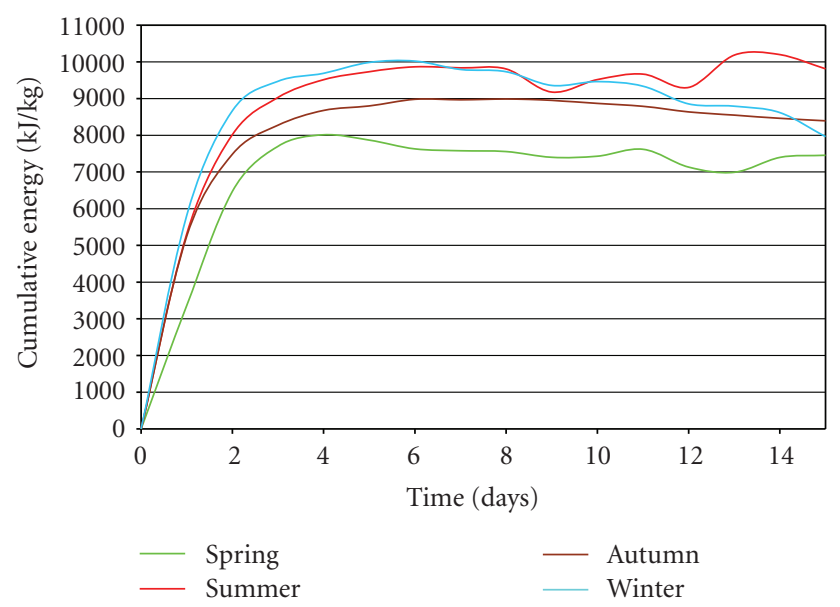

(b)

Figure 5: (a) Heat stored in compost, and (b) cumulative heat stored by compost; seasonal values.

Cumulative energy values ranged from approximately 7000 to $10000 \mathrm{~kJ} \mathrm{~kg}^{-1}$. These values related well to those reported by Ekinci at al. [19] for biosolids and wood chips $\left(8092 \mathrm{~kJ} \mathrm{~kg}^{-1}\right)$ and Steppa [24] for organic waste (9000-11000 $\mathrm{kJ} \mathrm{kg}^{-1}$ ), but were lower than that reported by Sobel and Muck [13] for poultry droppings (12800 $\mathrm{kJ} \mathrm{kg}^{-1}$ ), and by Stainforth [12] for wheat straw $\left(17600 \mathrm{~kJ} \mathrm{~kg}^{-1}\right)$. Additionally, they were greater than that for paper mill sludge and poultry manure compost $\left(3649 \mathrm{~kJ} \mathrm{~kg}^{-1}\right)$, and that for straw and poultry manure compost $\left(5111 \mathrm{~kJ} \mathrm{~kg}^{-1}\right)$ [23]. Differences in cumulative energy values are due to differences in decomposition rates under different conditions and heat of combustion values of the different composting substrates, which lead any direct comparisons being difficult to arrive upon and ultimately ineffectual. However, it is clear that, as these values are in line with a section of the existing research, they are reliable figures which may be utilised appropriately for subsequent calculations. The main reason for seasonal variation is likely due to the difference in material that is available during that particular season. For example, there will be less nitrogen rich material such as grass cuttings 
TABLE 5

\begin{tabular}{|c|c|c|c|c|}
\hline \multirow{2}{*}{\multicolumn{2}{|c|}{ Inlet temperatures }} & $T_{c, i}$ & 0 & ${ }^{\circ} \mathrm{C}$ \\
\hline & & $T_{h, i}$ & 65 & ${ }^{\circ} \mathrm{C}$ \\
\hline \multirow{5}{*}{\multicolumn{2}{|c|}{ Cold fluid flow rate (water pump) }} & Flow rate & 3 & $\mathrm{Lmin}^{-1}$ \\
\hline & & & 0.00005 & $\mathrm{~m}^{3} \mathrm{~s}^{-1}$ \\
\hline & & Density water & 999 & $\mathrm{~kg} \mathrm{~m}^{3}$ \\
\hline & & Flow rate & 0.04995 & $\mathrm{~kg} \mathrm{~s}^{-1}$ \\
\hline & & $m \operatorname{dot} c$ & 0.04995 & $\mathrm{~kg} \mathrm{~s}^{-1}$ \\
\hline \multirow{4}{*}{\multicolumn{2}{|c|}{ Hot fluid flow rate (blower at average capacity) }} & $m \operatorname{dot} h$ & 2000 & $\mathrm{~m}^{3} \mathrm{hr}^{-1}$ \\
\hline & & Density air & 1.2 & $\mathrm{~kg} \mathrm{~m}^{3}$ \\
\hline & & & 2400 & $\mathrm{~kg} \mathrm{hr}^{-1}$ \\
\hline & & $m \operatorname{dot} h$ & 0.66667 & $\mathrm{~kg} \mathrm{~s}^{-1}$ \\
\hline \multirow{2}{*}{\multicolumn{2}{|c|}{ Specific heat capacities }} & $c_{p, c}$ & 4.19 & $\mathrm{~kJ} \mathrm{~kg}^{-1} \mathrm{~K}^{-1}$ \\
\hline & & $c_{p, h}$ & 1.004 & $\mathrm{~kJ} \mathrm{~kg}^{-1} \mathrm{~K}^{-1}$ \\
\hline \multirow{4}{*}{\multicolumn{2}{|c|}{ Pipe properties (stainless steel) }} & $d_{i}$ & 0.02465 & $\mathrm{~m}$ \\
\hline & & $d_{o}$ & 0.02667 & $\mathrm{~m}$ \\
\hline & & Thickness & 0.00202 & $\mathrm{~m}$ \\
\hline & & $k_{w}$ & 16.3 & 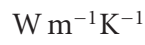 \\
\hline \multirow{2}{*}{ Heat transfer coefficients } & $\Delta Q$ & $h_{c}$ & 1200 & $\mathrm{~W} \mathrm{~m}^{-2} \mathrm{~K}^{-1}$ \\
\hline & $n=\overline{A \times \Delta T \times \Delta t}$ & $h_{h}$ & 50 & $\mathrm{~W} \mathrm{~m} \mathrm{~m}^{-2} \mathrm{~K}^{-1}$ \\
\hline \multirow{2}{*}{ Heat capacity rates } & & $C_{c}$ & 209.2905 & $\mathrm{~W} \mathrm{~K}^{-1}$ \\
\hline & $C=m c_{p}$ & $C_{h}$ & 669.3333 & $\mathrm{~W} \mathrm{~K}^{-1}$ \\
\hline \multirow{2}{*}{ Heat capacity ratio } & $C^{*}=\frac{C_{\min }}{}$ & $C_{\min }$ & 209.2905 & $\mathrm{~W} \mathrm{~K}^{-1}$ \\
\hline & $\overline{C_{\max }}$ & $C^{*}$ & 0.31269 & \\
\hline Fouling capacity (standard) & & $R_{w, f}$ & 0.002 & $\mathrm{~m}^{2} \mathrm{KW}^{-1}$ \\
\hline \multirow{6}{*}{ Overall heat transfer coefficient } & & $1 / h_{h}$ & 0.02 & \\
\hline & & $d_{0} / h_{c} d_{i}$ & 0.0009015 & \\
\hline & 1 & Wall & 0.0000644 & \\
\hline & 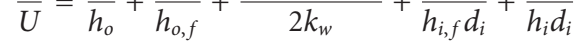 & Fouling inside & 0.0021637 & \\
\hline & & Fouling outside & 0.002 & \\
\hline & & $U$ & 39.7936 & $\mathrm{~W} \mathrm{~m}^{2} \mathrm{~K}^{-1}$ \\
\hline Pipe total surface area & & $A$ & 7.96 & $\mathrm{M}^{2}$ \\
\hline NTU & $\mathrm{NTU}=\frac{\mathrm{UA}}{C_{\min }}$ & NTU & 1.5135 & \\
\hline \multirow{3}{*}{$E$} & & eqn top line & 0.6466 & \\
\hline & $\varepsilon=\frac{1-\exp \left[-1-C^{*} \exp \left[-\mathrm{NTU}\left(1-C^{*}\right)\right]\right.}{1-C^{2}}$ & eqn bottom line & 0.8895 & \\
\hline & & $E$ & 0.7270 & \\
\hline \multirow{4}{*}{\multicolumn{2}{|c|}{ Outlet temperatures $\quad \varepsilon=\frac{C_{h}\left(T_{h, i}-T_{h, o}\right)}{C_{\min }\left(T_{h, i}-T_{c, i}\right)}=\frac{C_{c}\left(T_{c, o}-T_{c, i}\right)}{C_{\min }\left(T_{h, i}-T_{c, i}\right)}$}} & $T_{h, i}-T_{h, o}$ & 14.7750 & \\
\hline & & $T_{h, o}$ & 50.2250 & ${ }^{\circ} \mathrm{C}$ \\
\hline & & $T_{c, o}-T_{c, i}$ & 47.2520 & \\
\hline & & $T_{c, o}$ & 47.2520 & ${ }^{\circ} \mathrm{C}$ \\
\hline \multirow{2}{*}{\multicolumn{2}{|c|}{ Energy balance check }} & $q$ & 9889.3897 & $\mathrm{~kW}$ \\
\hline & & $T_{h, o}$ & 50.2250 & $\mathrm{C}$ \\
\hline \multirow{2}{*}{\multicolumn{2}{|c|}{ Pipe length needed }} & Surface area & 0.0838 & $\mathrm{~m}^{2} \mathrm{~m}^{-1}$ \\
\hline & & Pipe length & 95.0036 & $\mathrm{~m}$ \\
\hline
\end{tabular}

during the autumn and winter months, thus resulting in a lower overall energy content.

3.2. Heat Exchanger and Potential Uses for the Gathered Heat. All design parameters are summarised in Table 5, and the pipe layout in the in-vessel unites shown in Figure 6. These layouts provide enough length whilst managing to avoid contact points such as temperature probe holes and exhaust air outtakes. Using this particular pipe dimension leads to the hot and cold fluid exit temperatures that are presented in Table 6. These have been calculated for varying cold water inlet temperatures, due to the potential seasonal variability, 
TABLE 6: Outlet fluid temperatures at varying inlet temperatures.

\begin{tabular}{lccc}
\hline $\begin{array}{l}\text { Temperature of cold water entering } \\
\text { system }\end{array}$ & $0^{\circ} \mathrm{C}$ & $5^{\circ} \mathrm{C}$ & $10^{\circ} \mathrm{C}$ \\
\hline $\begin{array}{l}\text { Temperature of cold water leaving } \\
\text { system }\end{array}$ & $47.3^{\circ} \mathrm{C}$ & $48.6^{\circ} \mathrm{C}$ & $50.0^{\circ} \mathrm{C}$ \\
$\begin{array}{l}\text { Temperature of hot air leaving system } \\
50.2^{\circ} \mathrm{C}\end{array}$ & $51.4^{\circ} \mathrm{C}$ & $52.5^{\circ} \mathrm{C}$ \\
\hline
\end{tabular}

and an initial air temperature of $65^{\circ} \mathrm{C}$ in each case. According to these values, the hot water could be transferred to a storage vessel site office and used to supplement the hot water supply. The predicted daily demand of $180 \mathrm{~L} \mathrm{day}^{-1}$ could be met in full by the heat exchanger, which runs at a flow rate of $3 \mathrm{~L} \mathrm{~min}^{-1}$. This would remove the need for gas or electricity to provide hot water. However, in order to meet storage legislation [25] the temperature of the stored water must exceed $60^{\circ} \mathrm{C}$ at all times. Currently the heated water leaving the tunnel heat exchanger system is at a temperature between $47.3^{\circ} \mathrm{C}$ and $50^{\circ} \mathrm{C}$, depending on the temperature of the cold water entering the system. However, if the water exiting a tunnel is put through another tunnel in which degradation is also underway then higher temperatures can be achieved. For example, calculations based on an initial cold water feed of $0^{\circ} \mathrm{C}$ and initial hot air temperatures of $65^{\circ} \mathrm{C}$ result in temperatures of $0^{\circ} \mathrm{C}, 47.3^{\circ} \mathrm{C}, 60.2^{\circ} \mathrm{C}$, and $63.7^{\circ} \mathrm{C}$ by passing water through $0,1,2$, and 3 tunnels in series. Thus, by passing the same volume of water through 2 or 3 in-vessel tunnels, the required storage temperature of $60^{\circ} \mathrm{C}$ can be achieved. As the hot air is at an approximate temperature of $65^{\circ} \mathrm{C}$, then passing the water through more than three in-vessel tunnels has little improved effect and is likely inefficient practice.

The main issue with this use is that it requires at least two tunnels to be operating at the same time. If considering the usage over the past year as an accurate gauge then two or more tunnels are running simultaneously on $91 \%$ of days and three or more tunnels are running simultaneously on $78 \%$ of days (Calculations and graphical solution behind these statements not shown). It can be suggested therefore that domestic hot water supply, which requires a higher temperature for storage, can be supplied at least $78 \%$ of the time whilst underfloor spatial heating, as discussed below, can be provided $91 \%$ of the time. Another issue is that this system will require additional infrastructure to facilitate the level of control needed to direct the water into the correct tunnels. Two-way switch valves can be installed which could be controlled manually or by computer if required.

If underfloor heating is provided in the new site office then it may be feasible to provide the hot water for the system. Standard operating procedure for underfloor heating is to have an inlet temperature of $55^{\circ} \mathrm{C}$ and a return flow at $45^{\circ} \mathrm{C}$. The water will therefore have to be passed through two in-vessel tunnels in series and so provide $91 \%$ of the yearly demand. Standard underfloor systems require a heated water flow rate in the region of $1.55 \mathrm{~L} \mathrm{~min}^{-1}$ [26]. The heat exchanger element has been designed with a flow rate of $3 \mathrm{~L} \mathrm{~min}^{-1}$ so is capable of meeting demand. Water could be stored thus allowing the pumps to be run for fewer hours
TABLE 7: Solar thermal domestic hot water supply system specification.

\begin{tabular}{ll}
\hline Parameter & Design value \\
\hline Solar collector type & Evacuated tube \\
Solar collector area & $4.18 \mathrm{~m}^{2}$ \\
Heat store tank & $277 \mathrm{~L}$ \\
Solar circuit piping diameter & $8.86 \mathrm{~mm}$ \\
High temperature expansion vessel & $18 \mathrm{~L}$ \\
\hline
\end{tabular}

each day or the pump could be run at a lower capacity thus improving temperature gain further.

3.3. Solar Thermal System. The level of potential solar energy supply is $860 \mathrm{kWh} \mathrm{m}^{-2}$ year ${ }^{-1}$, while the predicted hot water demand for the site office of the Deerdykes composting facility is $180 \mathrm{~L} \mathrm{day}^{-1}$ and the hot water energy demand is $6.8 \mathrm{kWh} \mathrm{day}^{-1}$. These supply and demand parameters led to the quantification of the solar thermal system components as shown in Table 7 . The predicted performance of this system is to provide $60 \%$ of the offices yearly hot water demand. The remaining $40 \%$ will have to be provided by an auxiliary conventional boiler system. Regarding the design for spatial heating, for a heated living area of $200 \mathrm{~m}^{2}$, the evacuated tube surface area chosen for design was $12.53 \mathrm{~m}^{2}$, and the store volume $700 \mathrm{~L}$.

3.4. Ground Source Design. The method utilised to size and cost a suitable ground source heat pump system is very simplified and will not provide wholly accurate or reliable answers. This process was carried out in order to provide a comparison of typical cost and performance level of alternate renewable sources and is therefore for guidance purposes only. If a more detailed design is to be carried out a full site survey will be required to determine ground conditions and the levels of thermal insulation provided by the site office.

3.5. Cost Benefit Analysis. Table 8 summarises the cost per kWh of energy generated for each of the three possible methods. This cost is based solely on the annual operating cost required to run the system. Capital costs are provided for information and comparative purposes only and are not a factor in the cost per kWh calculation. The fraction of spatial heating provided is based on supplying a standard underfloor heating system with an input temperature of $55^{\circ} \mathrm{C}$. Capital costs do not include the underfloor heating system or the heating network itself. These should be similar if not identical for each system.

From this it is clear that reusing the heat offered by the compost is an economically attractive option when compared to alternate possible renewable sources. It is able to provide the highest proportion of the total hot water requirement of the three systems. Although comparative costs per $\mathrm{kWh}$ are greater than for solar thermal regarding domestic hot water supply and greater than ground source heat pump regarding spatial heating, these supplies will have 

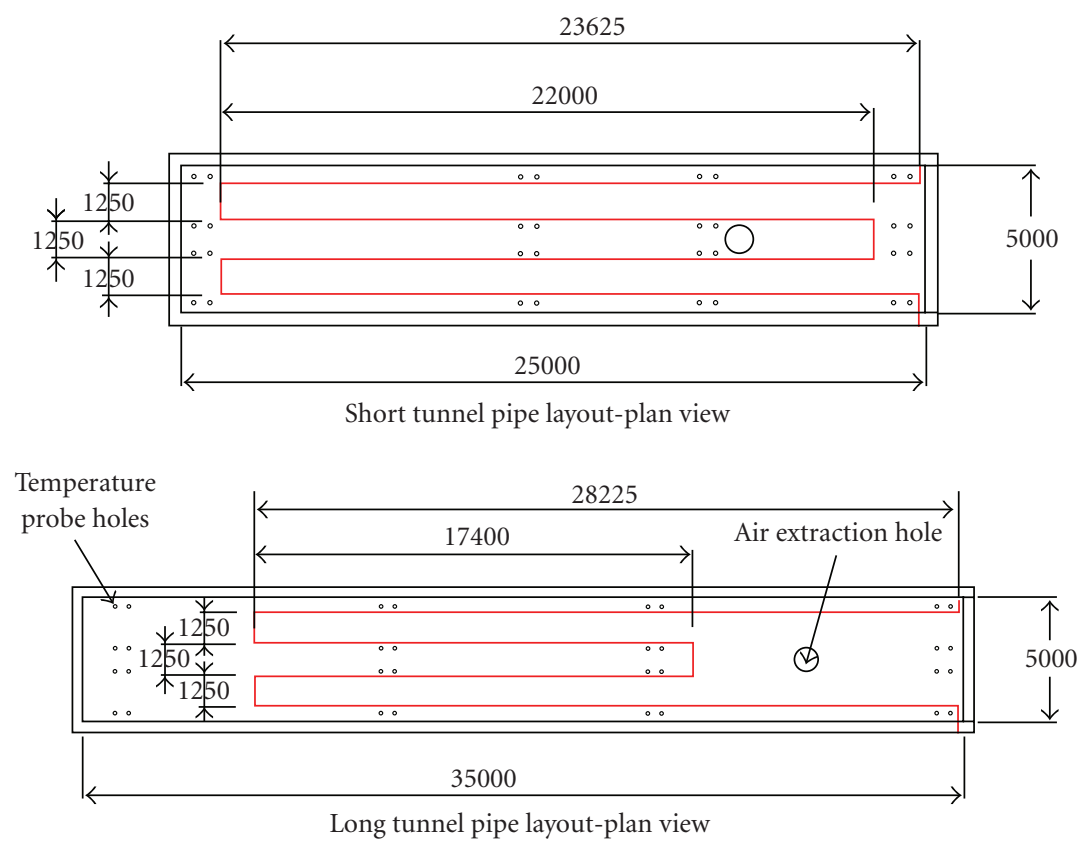

FIGURE 6: Suggested pipe layout for short and long in-vessel units.

TABle 8: Costs benefit analysis.

\begin{tabular}{|c|c|c|c|c|c|c|}
\hline \multirow{2}{*}{ Method } & \multicolumn{2}{|c|}{ Compost heat } & \multicolumn{2}{|c|}{ Solar thermal } & \multicolumn{2}{|c|}{ Ground source heat pump } \\
\hline & $\begin{array}{l}\text { Domestic hot } \\
\text { water supply }\end{array}$ & Spatial heating & $\begin{array}{l}\text { Domestic hot } \\
\text { water supply }\end{array}$ & Spatial heating & $\begin{array}{l}\text { Domestic hot } \\
\text { water supply }\end{array}$ & Spatial heating \\
\hline Capital cost $(\mathfrak{E})$ & \multicolumn{2}{|c|}{11662} & 4180 & 13415 & \multicolumn{2}{|c|}{5413} \\
\hline Operating Cost $\left(\mathfrak{E} \mathrm{yr}^{-1}\right)$ & \multicolumn{2}{|c|}{1039} & 625 & 940 & \multicolumn{2}{|c|}{840} \\
\hline Fraction Provided & $78 \%$ & $91 \%$ & $60 \%$ & $35 \%$ & $50 \%$ & $100 \%$ \\
\hline $\mathrm{kWh} \mathrm{yr}^{-1}$ required & 2667 & 11760 & 2667 & 11760 & 2667 & 11760 \\
\hline Cost per kWh $(\mathfrak{E})$ & 0.4994 & 0.0971 & 0.3905 & 0.2284 & 0.6298 & 0.0714 \\
\hline
\end{tabular}

to be boosted to a greater degree by additional conventional boiling.

The capital cost of using the heat from the compost, although large, is also attractive when compared to its competitors. Although the ground source heat pumps capital cost is lower, this initial gain will soon be lost with the high level of additional hot water heating required to provide domestic hot water supply. This cost assumes all 8 tunnels will have a heat exchanger element installed, thus increasing reliability. A cost that has not been included is the valve control system that directs the water into the correct tunnels. This could be controlled manually, but an appropriate computer controlled system will guarantee a reliable supply of water. The expenditure of such a product has not been included.

\section{Conclusions}

The amount of energy that could be obtained from composting at the Deerdykes composting facility near Glasgow has been calculated as between 7000 and $10000 \mathrm{~kJ} \mathrm{~kg}^{-1}$ for a 15 -day composting period. The variations were likely due to seasonal differences in conditions and raw material supply.
The results were in line with alternate existing investigations into material of similar composition. This showed that the compost contained a usable amount of energy if it could be gathered.

Methods of extracting the heat were fully researched. A solution of absorbing the heat contained in the expelled air in the tunnel space above the compost was put forward. A bespoke air-water heat exchanger utilising stainless steel piping was designed and specified. The outlet temperature of the water was shown to be $47.3^{\circ} \mathrm{C}$. This can be shown to rise to above $60^{\circ} \mathrm{C}$ if the water is passed through multiple tunnels in series.

Several usable purposes were suggested for this heated water, including contributing to the site offices hot water demand and process optimisation. Adequate levels of heated water were shown to be provided for the domestic hot water and spatial heating supplies for $78 \%$ and $91 \%$ of the time, respectively.

Installing this system was submitted to preliminary costing in order to calculate a cost per kWh of energy that could be displaced by using the heat of the compost. This cost was then compared with that of specially designed solar 
thermal and ground source heat pump systems. From this the heat exchanger system could be put into a real world context. The system was found to provide the most reliable supply of the three systems, and to do so at a very competitive price of $\mathfrak{E} 0.499$ and $\mathfrak{E} 0.097$ per $\mathrm{kWh}$ for domestic hot water supply and spatial heating, respectively. It can therefore be concluded that collecting the waste heat of compost through a heat exchanger is a realistic solution to contributing to energy demand.

Further investigations to maximize the production of heat from in-vessel units are ongoing.

\section{Acknowledgments}

The authors are grateful to Andrew Meldrum and Donald MacBrayne (Deerdykes Composting Facility), for providing data and information required for the completion of this paper. They are also grateful to Paul Steen (Ramboll UK), for providing advice on particular aspects of this paper. They also thank Paolo Pironi (University of Edinburgh) for providing access to thermocouples for further collection of temperature readings outside the composting vessels.

\section{References}

[1] R. T. Haug, Compost Engineering: Principles \& Practice, Ann Arbor Science Publishers, Ann Arbor, Mich, USA, 1980.

[2] EC, EU Animal By-Products Regulations (2003/31/EEC), European Commission, 2003.

[3] B. Antizar-Ladislao, A. J. Beck, K. Spanova, J. Lopez-Real, and N. J. Russell, "The influence of different temperature programmes on the bioremediation of polycyclic aromatic hydrocarbons (PAHs) in a coal-tar contaminated soil by invessel composting," Journal of Hazardous Materials, vol. 144, no. 1-2, pp. 340-347, 2007.

[4] L. Allievi, A. Marchesini, C. Salardi, V. Piano, and A. Ferrari, "Plant quality and soil residual fertility six years after a compost treatment," Bioresource Technology, vol. 43, no. 1, pp. 85-89, 1993.

[5] M. Chapman and B. Antizar-Ladislao, "Biotic landfill $\mathrm{CH}_{4}$ emission abatement using bio-waste compost as a landfill cover," in Landfill Research Focus, E.C. Lehmann, Ed., Nova Science Publishers, New York, NY, USA, 2007.

[6] H. Insam, N. Riddech, and S. Klammer, Microbiology of Composting, Springer, Berlin, Germany, 2002.

[7] K. Sipilä, A. Johansson, and K. Saviharju, "Can fuel-based energy production meet the challenge of fighting global warming - a chance for biomass and cogeneration?" Bioresource Technology, vol. 43, no. 1, pp. 7-12, 1993.

[8] EEA, "State of renewable energies in Europe 2006," 2008, http: //www.energies-renouvelables.org/observer/stat/baro/barobilan/barob-ilan6.pdf.

[9] B. Antizar-Ladislao and J. L. Turrión-Gómez, "Secondgeneration biofuels and local bioenergy systems," Biofuels, Bioproducts and Biorefining, vol. 2, no. 5, pp. 455-469, 2008.

[10] E. Klejment and M. Rosiński, "Testing of thermal properties of compost from municipal waste with a view to using it as a renewable, low temperature heat source," Bioresource Technology, vol. 99, no. 18, pp. 8850-8855, 2008.

[11] N. Guljajew and M. Szapiro, "Determining of heat energy volume released by waste during biothermal disposal," in Sbornik
Naucznych Robot, pp. 135-141, Akademija Kommunalnowo Chozjajstwa, Moskow, Russia, 1962.

[12] A. Stainforth, Cereal Straw, Clarendon, Oxford, UK, 1979.

[13] A. T. Sobel and R. E. Muck, "Energy in animal manures," Energy in Agriculture, vol. 2, pp. 161-176, 1983.

[14] S. Lekic, Possibilities of Heat Recovery from Waste Composting Process, Centre for Sustainable Development, Department of Engineering, University of Cambridge, Cambridge, UK, 2005.

[15] H. Seki and T. Komori, "Packed-column-type heating tower for recovery of heat generated in compost," Journal of Agricultural Meteorology, vol. 48, pp. 237-246, 1992.

[16] S.D. Last, D. MacBrayne, and A. J. MacArthur, "Deedykes Composting Facility: a case study of the conversion of a conventional activated sludge sewage works to in-vessel composting, with slude co-composting facility," in Proceedings of Kalmar Eco-Tech and The 2nd Baltic Symposium on Environmental Chemistry, Kalmar, Sweden, 2005.

[17] DGS, Planning and Installing Solar Thermal Systems: A Guide for Installers, Architects and Engineers, James \& James, London, UK, 2005.

[18] P. S. Doherty, S. Al-Huthaili, S. B. Riffat, and N. Abodahab, "Ground source heat pump-description and preliminary results of the Eco House system," Applied Thermal Engineering, vol. 24, no. 17-18, pp. 2627-2641, 2004.

[19] K. Ekinci, H. M. Keener, and D. Akbolat, "Effects of feedstock, airflow rate, and recirculation ratio on performance of composting systems with air recirculation," Bioresource Technology, vol. 97, no. 7, pp. 922-932, 2006.

[20] R. K. Shah and D. P. Sekulic, Fundamentals of Heat Exchanger Design, John Wiley \& Sons, Hoboken, NJ, USA, 2003.

[21] R. D. Heap, Heat Pumps, E. \& F.N. Spon, London, UK, 1979.

[22] K. Ekinci, Theoretical and Experimental Study on the Effects of Aeration Strategies on the Composting Process, Department of Agricultural Engineering, The Ohio State University, Columbus, Ohio, USA, 2001.

[23] E. Harper, F. C. Miller, and B. J. Macauley, "Physical management and interpretation of an environmentally controlled composting ecosystem," Australian Journal of Experimental Agriculture, vol. 32, pp. 657-667, 1992.

[24] M. Steppa, " Two options for energy recovery from waste biomass," Maszyny i Ciagniki Rolnicze, no. 3, 1988.

[25] HSE, "Legionnaires disease: essential information for providers of residential accommodation," Health and Safety Executive, 2003.

[26] Oxyvent, "The Oxyvent Tank: Underfloor heating / Radiant heating," 2009, http://www.oxyvent.com/underfloorheating .php. 

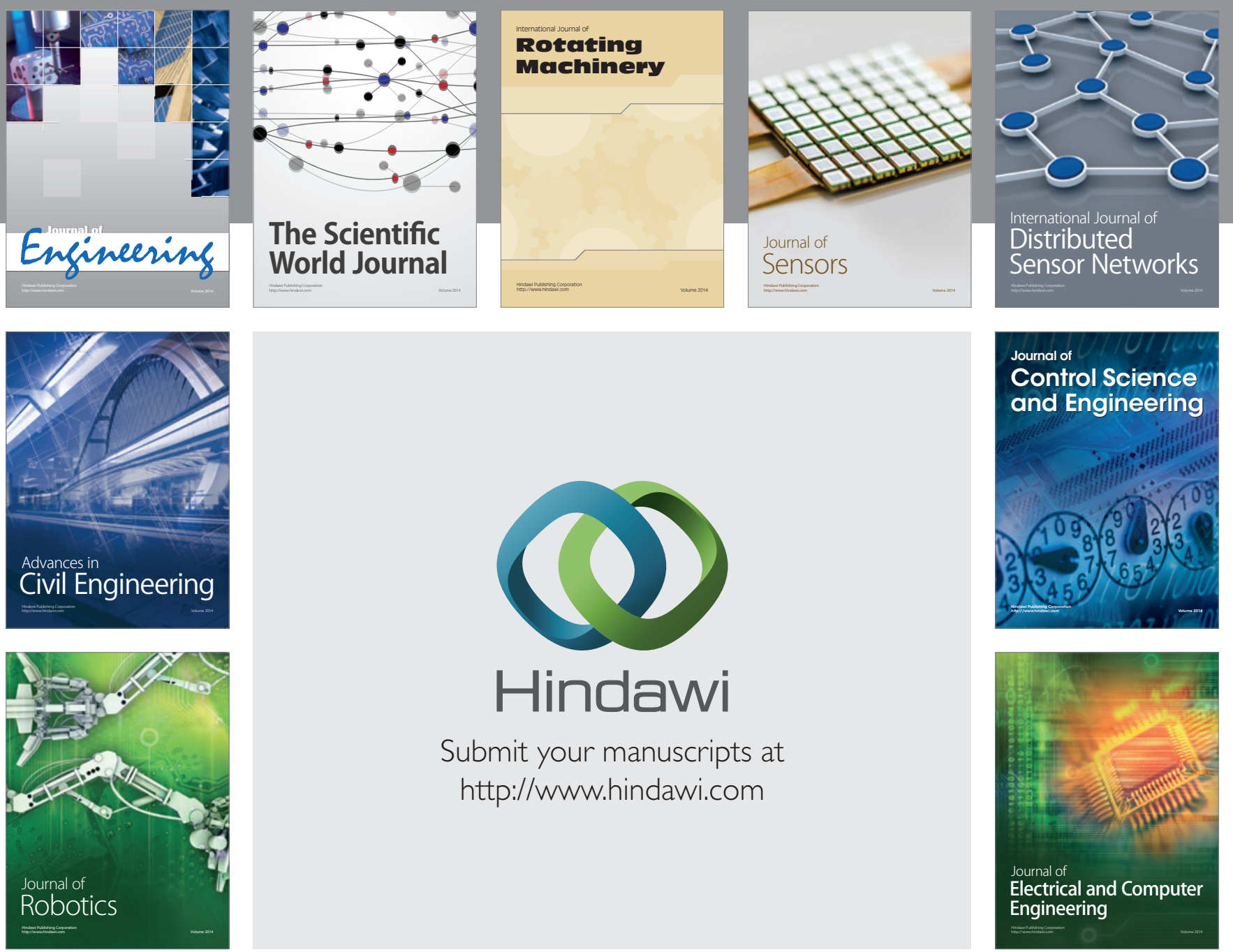

Submit your manuscripts at

http://www.hindawi.com
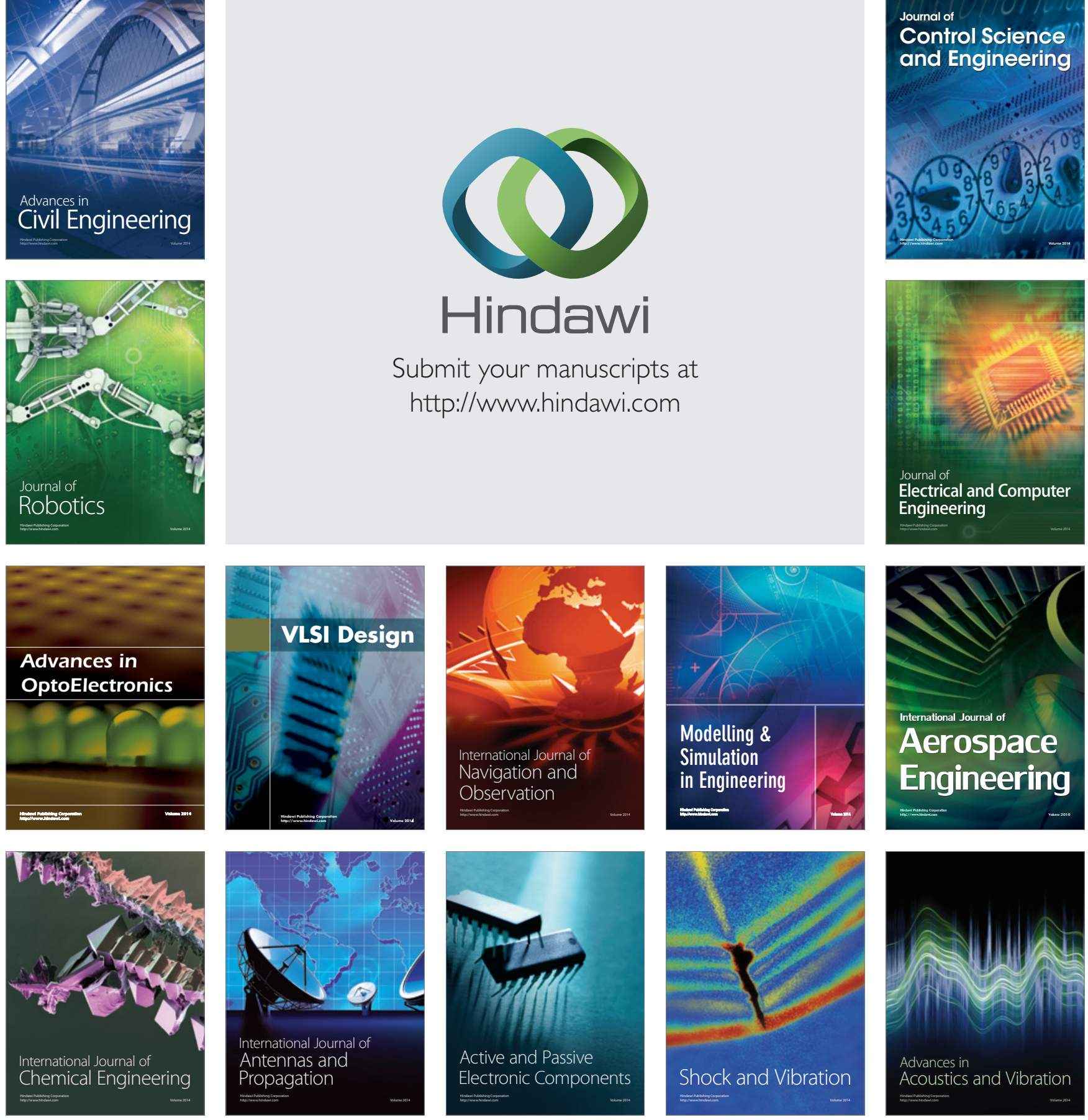